\title{
Commercialization of University Research in Canada: What Can We Do Better?
}

\author{
Viktoriya Galushko $^{1} \&$ Ken Sagynbekov ${ }^{1}$ \\ ${ }^{1}$ Economics Department, University of Regina, Regina, Canada \\ Correspondence: Viktoriya Galushko, Associate professor, Economics Department, University of Regina, Regina, \\ Canada. E-mail: viktoriya.galushko@uregina.ca
}

Received: August 1, 2014

Accepted: August 12, 2014

Online Published: August 22, 2014

doi:10.5430/ijba.v5n5p1

URL: http://dx.doi.org/10.5430/ijba.v5n5p1

\begin{abstract}
In 2011/2012, Canada spent about CAN\$11.5 billion on research and development in the higher education sector, which is about one-third of total R\&D activities in Canada. There is no doubt that Canadian universities have played an important role in knowledge generation. At the same time Canada has been lagging in terms of how fast the generated knowledge is translated into economically and socially beneficial products and processes. This paper draws upon the interviews with technology transfer officers and life-science faculty at nine Canadian universities. The government and institutional initiatives to promote commercialization of research are discussed and hindrances to mobilization of university research are identified.
\end{abstract}

Keywords: commercialization, innovation, university research

\section{Introduction}

The government of Canada set a goal to transform the country into a world leader in developing the $21^{\text {st }}$ century technologies and increasing commercialization of new technologies (Note 1). To this end the federal government launched a number of initiatives to promote commercialization. In 2002, as part of an agreement between the federal government and the Association of Universities and Colleges of Canada (AUCC), Canadian universities committed to double their research funding and triple their commercialization efforts by 2010. In 2007, the government launched the new Canada's science and technology strategy with the goal of encouraging businesses to invest in research and development and to bring new ideas into the marketplace for the benefit of all Canadians. Through the 2006, 2007, and 2008 budgets, the government provided an additional $\$ 2.2$ billion in new funding for science and technology initiatives.

Over the last decade, commercialization efforts at Canadian universities have developed into an integral part of research and innovation activities (Fisher and Atkinson-Grosjean 2002). The number of invention disclosures by universities increased from 661 in 1998 to 1,428 in 2009 and the number of patent applications filed increased from 379 in 1998 to 1,593 in 2009. Licensing income generated by Canadian universities has almost quadrupled, rising from CAN\$16.3 million in 1998 to \$67.4 million in 2009 (Statistics Canada, CANSIM 358-0025).

Despite Canada's strength in research and increased commercialization efforts, numerous sources have reported that Canada still lags behind other countries in converting this strength into a commercial success (Agrawal, 2006a; Conference Board of Canada, 2008; Munroe-Blum and MacKinnon, 2009; Yakabuski, 2009). The "D" grades on most indicators of innovative activity reveal Canada's weakness in translating publicly funded research into products with a high level of global market penetration (Conference Board of Canada 2013). To enhance Canada's R\&D competitiveness, fostering commercialization is now the key element of the innovation policy. The shift towards commercialization is evident in the redirection of public funds from basic to applied research for National Research Council (NRC) research (Den Tandt 2013).

Given the policy shift towards commercialization, a number of interesting questions arise: Have the government programs been effective in fostering technology transfer? How are universities adjusting to commercialization pressures? What are the implications of increased emphasis on commercialization for public research? Is commercialization consistent with a university mission? What are the main hindrances to commercialization of university research in Canada? It is these questions that inform our investigation. 
The analysis presented in this paper draws upon personal interviews with nine technology transfer officers (TTOs) and seventeen faculty members in life science departments from eight Canadian universities (Note 2). The interviews were conducted in full compliance with the University of Regina Ethics Board requirements and followed an open-ended structure to encourage the participants to fully express their opinions about technology transfer from universities. Since commercialization incidences and practices vary widely across the disciplines, this study is confined to life-sciences, namely, molecular biology, biochemistry, biology, microbiology and immunology, botany, and cell biology. Faculty members at a rank of Associate Professor or higher in life-science departments from the aforementioned eight universities were approached with a request for an interview. About 40 percent of the faculty members responded, and the majority of them indicated that they had no experience with technology transfer. For the purpose of this study, the most relevant group of faculty members was faculty members who had produced commercially viable innovations throughout their careers. Out of those who responded, only seventeen faculty members indicated that they had ever developed a potentially commercializable innovation and were, therefore, selected for the interview. Furthermore, the faculty survey is dominated by the responses from the University of British Columbia, which is the hub of commercialization activities in the area of life-sciences. Perceptions about technology transfer from universities could be more accurately assessed if more faculty members from smaller universities were willing to participate. Nevertheless, we feel that seventeen faculty interviews and nine interviews with TTOs have been sufficient to reach the point of theoretical saturation (Holstein and Gubrium, 1995).

This paper is organized in three parts. The first part outlines government and institutional initiatives to promote commercialization of university research. The discussion of the initiatives is complemented by interviewees' comments with regards to their effectiveness. The second part describes the weaknesses of the current commercialization policy as perceived by the participants. Drawn on the survey results, the third part highlights the major hindrances to commercialization of university research in Canada. The paper concludes with a summary of results and their policy implications.

\section{From the University Lab to the Market: Measures to Promote Commercialization}

\subsection{Government Initiatives to Foster Commercialization of University Research in Life-Sciences in Canada}

The commercialization gap in Canada was first addressed in 1993 by the Canadian University Intellectual Property Group (CUIPG). Since then, a number of government initiatives have been launched to support and promote commercialization of university research.

The Intellectual Property Mobilization (IPM) Program, established in 1995 and initially funded through the Natural Sciences and Engineering Research Council (NSERC), was one of the first programs directed at strengthening the ability of universities to manage and commercialize their IPs. In 2001 the Canadian Institute of Health Research (CIHR) and Social Sciences and Humanities Research Council (SSHRC) joined the program and it was expanded beyond natural sciences and engineering fields. Starting in 2002, the program also allocated funds to train technology transfer personnel for universities. The IPM was discontinued in 2009. Throughout its 14-years of existence, more than 107 institutions participated in IPM grants totalling \$59 million.

The federal government supported a number of strategic partnerships since the mid-1990s. The 1997 federal budget established the Canada Foundation for Innovation (CFI) with an initial investment of $\$ 800$ million. The CFI's mandate is to invest in research infrastructure thus strengthening universities' and colleges' abilities to conduct world-class science. Currently, the CFI has nine distinct funds. The funding criteria encourage universities to form partnerships with the private sector with the CFI covering up to 40 percent of a project's infrastructure costs. Since its creation, the CFI has received close to $\$ 5$ billion from the federal government and has committed the funds in support of over 8,000 projects at 144 research institutions in 68 municipalities across Canada. Only a portion of the CFI funds is designed to promote commercialization in life-sciences. The 2013 budget provided $\$ 225$ million of direct funding to the CFI. Figure 1 illustrates the allocation of CFI funds by sector of application. In addition, the 2013 budget provided for $\$ 37$ million per year in new funding to support research partnerships with industry through the grant councils. 


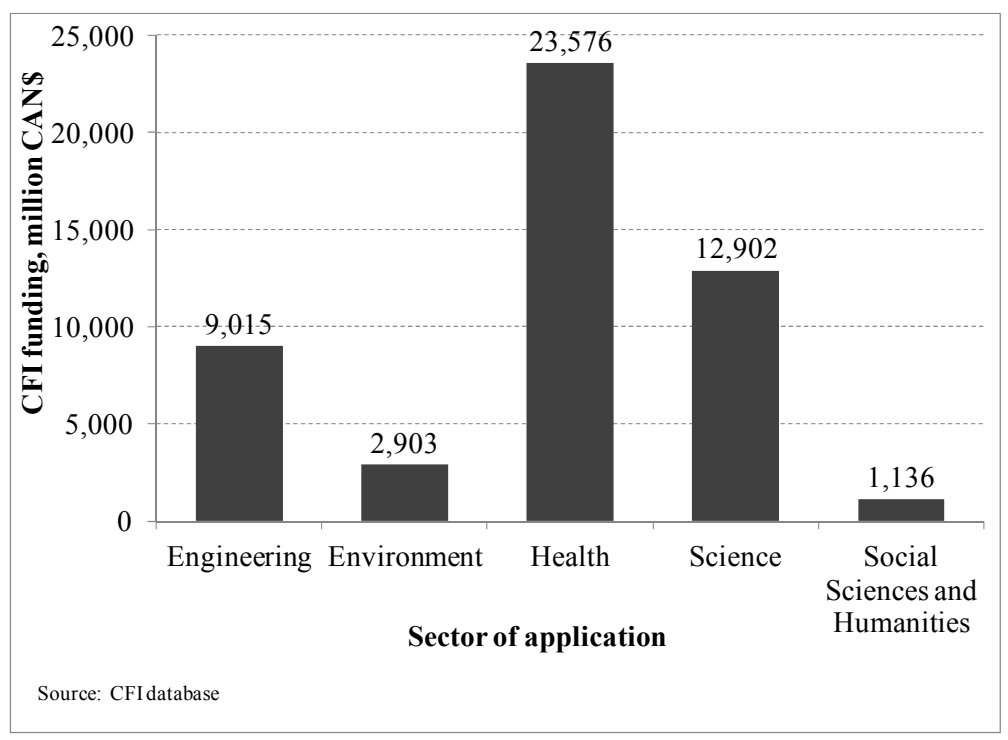

Figure 1. CFI funding to date by sector of application

CIHR has a budget for a program called Proof of Principle (POP) launched in 2001. The program encompasses discoveries in health sciences, anything from diagnostics to devices and to drugs. It provides funding for up to $\$ 160,000$ per grant with the possibility to allocate up to $20 \%$ of the requested budget for eligible expenses incurred in the commercialization stage including patenting cost, legal fees, market research cost, and others. The POP program offers two phases for grant application. For Phase I, partnership with the industry is not required; however, an innovation has to be at a stage where IP protection can be applied and a clear path to commercialization is identified. Phase II is aimed at providing a platform to better enable the academic institution/researcher to move the discovery/invention further down the innovation pipeline and requires participation of industry.

The NSERC Idea to Innovation (I2I) program launched in 2003 has also played a role in linking university researchers with Canadian businesses. Even though it is a relatively small-scale-grants program with an average award in the vicinity of $\$ 90$ thousand, it did receive awareness among the interviewed faculty members. The program aims at accelerating development of promising technologies and offers funding at different stages of technological maturation. The program allows faculty members to validate their ideas and get them to the reduced-to-practice stage where the private sector can clearly see the technology's benefits and commit funds to further develop the technology. To access the I2I funds for enhancement of the technology (Phase II funding), university researchers are required to have a private partner sharing the cost of the project. The I2I has funded more than 590 projects worth more than $\$ 53$ million.

In 2003, the federal government also launched the College and Community Innovation (CCI) pilot program that became a permanent CCI program in 2008. The program is administered through NSERC in partnership with SSHRC and CIHR and supports six grants. The main goals of the program are to enhance the links between colleges/universities and local businesses, boost the R\&D productivity of the private sector by improving access of small and medium-sized companies to technologies and equipment available at universities/colleges, and to enhance abilities of universities/colleges to conduct applied research through purchase of applied research equipment. Since 2002, the federal government has awarded $\$ 62.1$ million (Note 3). In 2011-12, 4,586 companies partnered with colleges on applied research projects (ACCC 2013). The Economic Action Plan 2013 provided additional $\$ 12$ millions of funding to the program.

An important role in supporting large-scale collaborations between universities, industry, government and non-for-profit organizations is played by the Networks of Centres of Excellence (NCE) created in 1997. The NCE operates a number of funding programs to mobilize Canada's research including the Centres of Excellence for Commercialization and Research (CERC) program that has been one of Canada's most successful programs to translate research ideas into innovative products. The CERC program was created in 2007 with an annual investment in innovation of about CAN $\$ 30$ million. Currently there are 21 centres all across Canada aimed at advancing world class research and facilitating technology transfer through strategic partnerships between academic institutions and 
business community. These centres concentrate their efforts in four priority areas - the environment, natural resources and energy, health and life sciences, and information and communications technologies.

One of the latest commercialization programs relevant for innovations in life-sciences is NSERC Engage Grants program launched in 2010. Engage grants are short-term (up to six months) grants of up to $\$ 25,000$ aimed at helping Canadian-based companies to get access to the knowledge and expertise available at Canadian universities. Partnership between university scientists and private companies is required under the program. Since its creation, the program supported more than 1,200 projects at 62 universities and colleges. Some faculty members indicated that short-term nature of the program undermines its effectiveness in life-sciences and the following quote supports this:

"it is really hard to do something in six months [within the NSERC Engage grant]. Especially when you have to train the new staff person like we did. By the time we got that person trained and working six months was almost over. So my real feeling about Engage was that it's a great idea but when I first heard it was six months I said "Well, why are we even bothering? What can you do in six months?"... especially when you are doing biological research everything takes time... Experiments take time.... if it had been a year at least or two years to me that would have been far more effective."

A summary of the programs intended to promote commercialization of life-science innovations is presented in Table 1.

Table 1. Summary of federal programs to promote commercialization of university research

\begin{tabular}{|c|c|c|c|}
\hline Program/Initiative & Administering body & $\begin{array}{l}\text { Years in } \\
\text { existence }\end{array}$ & $\begin{array}{l}\text { Value of } \\
\text { awards to } \\
\text { date, } \\
\text { CAN\$ million }\end{array}$ \\
\hline Intellectual Property Mobilization program & $\begin{array}{l}\text { NSERC, SSHRC, } \\
\text { CIHR }\end{array}$ & $1995-2009$ & 59.0 \\
\hline Technology Partnerships program & NSERC & $1997-2006$ & 9.5 \\
\hline University-Industry program & CIHR & $1999-2006$ & 30.5 \\
\hline Canada Foundation for Innovation & & 1997 - current & $5,000^{\mathrm{b}}$ \\
\hline Proof of Principle (POP) & CIHR & 2001 - current & $58.4^{\mathrm{c}}$ \\
\hline Idea to Innovation Program (I2I) & NSERC & 2003 - current & $53.4^{\mathrm{a}}$ \\
\hline College and Community Innovation Program & NSERC, SSHRC & 2003 - current & $62.2^{\mathrm{a}}$ \\
\hline $\begin{array}{l}\text { Commercialization Management Grants (CMG) } \\
\text { program }\end{array}$ & CIHR & $2004-2006$ & 0.7 \\
\hline $\begin{array}{l}\text { Centres of Excellence for Commercialization and } \\
\text { Research (CERC) }\end{array}$ & $\begin{array}{l}\text { NSERC, SSHRC, } \\
\text { CIHR }\end{array}$ & 2007 - current & $225.4^{\mathrm{a}}$ \\
\hline Engage Grants program & NSERC & 2010 - current & $31.2^{\mathrm{a}}$ \\
\hline \multicolumn{4}{|c|}{$\begin{array}{l}\text { Note: Only the programs that are relevant for innovations in life-sciences are listed. } \\
\text { a - funding up to 2011/2012 } \\
\text { b - funding up to 2012/2013 } \\
\text { c - funding up to 2013/2014 } \\
\text { Source: Authors' compilation from the SSHRC/NSERC Awards Search Engines and CIHR Awards Search. }\end{array}$} \\
\hline
\end{tabular}


While the federal programs were generally deemed effective in helping university researchers to move innovations down the commercialization pipeline, a number of inefficiencies were identified by the interviewed faculty. One participant indicated that close partnership with industry undermines students' rights to publicly disclose their research, which is supported by the following quote:

"NSERC has their new Engage program, that on the surface looks really good, and it gives about $\$ 25,000$ for a very well crafted, very tight strategic project for a company to go to a university group who has the know how to solve problems, and the company has a specific problem, and then at no cost to the company NSERC pays for somebody at the university to solve that problem. The problem goes back to one of my original comments on students' number one right - to be able to publicly disclose their technology and their research. I don't understand how you can have a university group solving a challenge of a company where the company owns all the IP and put a student on the project. I think you are only asking for trouble."

The second issue as identified by the faculty is the short-term nature of grants and insufficient funding for testing ideas in early stages of development. In order to benefit from the granting system, a university scientist has to be able to demonstrate efficacy within a year to two years, which, in many cases, is simply impossible as far as innovations in life-sciences are concerned. Furthermore, lack of adequate funding to support early testing of the quality of ideas makes it difficult for researchers to secure funding from the above mentioned initiatives that require ideas to be well-crafted and in most cases already validated.

The third inefficiency identified by one interviewee is that the current funding system does not incentivize or reward risk taking, because in a normal granting system everything is tied to specific goals. Risk taking is important to develop entrepreneurial spirit of university scientists and as was hypothesized by the interviewee availability of programs that would provide faculty members, those who demonstrated success for a certain time in the granting system, with money that is not tied to any specific goals could increase the number of breakthroughs and commercialization potential of universities.

One participant indicated that the Canadian granting system could be improved if it were progressive similar to what they have in the U.S.:

"I think that the National Institute of Health (NIH) has a better system than our federal granting agencies for giving out money. They seem to have a linear sequence. You get a Small Business Innovation Research (SBIR) stage one grant for the basic science principle. Then you get a stage two grant to develop the product. Then you get a stage three grant to get it out to market. You know they have different stages and once you pass stage one you can progress to stage two and three. But we don't seem to have such a linear sequence up at NSERC... It seems like the grants are not really integrated well with each other and they are not progressive in terms of when you get one then you move on to the next one and then you move on to the third one. They're sort of more hit and miss and so it's not a very progressive thing. I think the US system is good because it's progressive. It feeds people through a direct pipeline. I don't think the ones in Canada do. I think that's part of the problem."

\subsection{Institutional Initiatives to Foster Commercialization of University Research in Canada}

\subsubsection{Technology Transfer Offices (TTOs)}

To help university researchers commercialize their innovations, TTOs or industry liaison offices (ILOs) have been created in most universities. Generally, TTOs are funded by their respective universities sometimes in conjunction with support from municipal and provincial governments (Note 4). Commercialization process involves a lot of uncertainties and only a small proportion of commercialization attempts are successful resulting in significant financial rewards. Therefore, it is difficult for TTOs to be self-sustained and pay for their operational expenses from the generated licensing income especially during the first years of existence. Some TTOs, however, have gradually become self-sustained (Note 5).

TTOs fulfill a number of functions that begin from an innovation disclosure. The TTO staff evaluates a commercial potential of innovations, helps draft and file patents, engages potential partners and equity holders to develop either licenses or spin-off companies, and drafts contracts. Technology portfolios of TTOs have been substantially expanded in the last decade or so. Operational expenditures on intellectual property (IP) management increased from CAN\$12.6 million in 1998 to CAN\$56.7 million in 2009 (Statistics Canada, CANSIM 358-0025). To fulfill their 
missions, the offices are staffed with commercialization managers as well as lawyers specializing in IP. Table 2 provides information on staffing of TTOs and average load as measured by the number of disclosures per licensing full-time equivalent (FTE).

Table 2. Staffing and average commercialization load of TTOs at Canadian universities

\begin{tabular}{|c|c|c|c|c|}
\hline University & $\begin{array}{l}\text { Office responsible for } \\
\text { commercialization }\end{array}$ & $\begin{array}{l}\text { Is commercialization via TTO required if the } \\
\text { university has interest in the IP? }\end{array}$ & $\begin{array}{l}2011 \\
\text { Licensing } \\
\quad \text { FTE }\end{array}$ & $\begin{array}{l}2011 \\
\text { Invention } \\
\text { disclosures } \\
\text { per licensing } \\
\quad \text { FTE }\end{array}$ \\
\hline $\begin{array}{l}\text { University of } \\
\text { Guelph }\end{array}$ & Catalyst Centre & $\begin{array}{l}\text { No: "A member may, at his/her sole } \\
\text { discretion, make his/her own arrangements for } \\
\text { an application for patent or copyright and for } \\
\text { the commercial exploitation of any } \\
\text { invention..." }\end{array}$ & 5 & 36.2 \\
\hline $\begin{array}{l}\text { McGill } \\
\text { University }\end{array}$ & $\begin{array}{l}\text { Office of Technology } \\
\text { Transfer }\end{array}$ & $\begin{array}{l}\text { Yes: "Inventors shall not protect or } \\
\text { commercialize invention or software } \\
\text { independently of the university" }\end{array}$ & 5 & 19.6 \\
\hline $\begin{array}{l}\text { University of } \\
\text { Victoria }\end{array}$ & $\begin{array}{l}\text { UVic Industry } \\
\text { Partnerships }\end{array}$ & $\begin{array}{l}\text { Yes: "Where IP is anticipated to be } \\
\text { commercially viable, it shall be disclosed by } \\
\text { the University member on a confidential basis } \\
\text { at as early a stage of development as possible } \\
\text { to the University. In this manner, the } \\
\text { University shall ensure that it has the first } \\
\text { opportunity to offer its services through the } \\
\text { OVPR and the IDC as the vehicle for } \\
\text { commercialization." }\end{array}$ & 4 & 15.8 \\
\hline $\begin{array}{l}\text { University of } \\
\text { Manitoba }\end{array}$ & $\begin{array}{l}\text { Technology Transfer } \\
\text { Office }\end{array}$ & $\begin{array}{l}\text { No: "University Members may commercialize } \\
\text { jointly owned IP independent of the } \\
\text { University" }\end{array}$ & 4 & 15.3 \\
\hline $\begin{array}{l}\text { University of } \\
\text { Toronto }\end{array}$ & $\begin{array}{l}4 \text { partner companies: } \\
\text { Centre of } \\
\text { Regenerative } \\
\text { Medicine; Techna } \\
\text { Institute; MarS; } \\
\text { Innovations \& } \\
\text { Partnerships Office }\end{array}$ & $\begin{array}{l}\text { No: "If an Inventor wishes to take full } \\
\text { responsibility for the legal protection and/or } \\
\text { commercialization of an Invention, the } \\
\text { Inventor shall inform the University and the } \\
\text { University shall assign sole ownership of the } \\
\text { Invention to the Inventor subject to certain } \\
\text { obligations" }\end{array}$ & 15 & 12.8 \\
\hline $\begin{array}{l}\text { University of } \\
\text { British Columbia }\end{array}$ & $\begin{array}{l}\text { University-Industry } \\
\text { Liaison office }\end{array}$ & $\begin{array}{l}\text { Yes: "...the University maintains the } \\
\text { discretion to make decisions regarding the } \\
\text { mobilization of university research products } \\
\text { that have been disclosed to the university" }\end{array}$ & 10 & 12.4 \\
\hline
\end{tabular}


University of

Alberta

TEC Edmonton

McMaster

University

Waterloo

University of

Saskatchewan

Simon Fraser

University
No: "When an inventor wishes to have commercialization of IP undertaken by the university, the Vice-President (Research) shall decide whether to accept the responsibility for commercialization."

Yes: "The actual method of commercializing IP shall be the determination of the IP Board."

10

6.8

No: "Members of the University who have developed IP and intend to pursue commercialization, must inform the Vice-President in advance and in writing, of 3.4 the nature of the IP, and the intentions of the researcher(s) for it, so that he/she is aware of the activity and can respond to inquiries from external sources."

Yes: “... faculty and staff are required to sign an agreement with the university called the "Memorandum of Agreement Respecting Inventions". By the terms of this agreement, faculty and staff agree to transfer to the University their interests (ownership) in any Invention."

No: "Creators are free to commercialize their IP without involving the university in the 7 commercialization process"

Note: The third column provides the excerpts from the universities' IP policies

Source: AUTM (2011) and authors' compilations

The work done by the TTOs was appreciated by all of the interviewees. One interviewee indicated that:

"The big benefit of having the TTO involved is that it makes the license more secure."

A number of weaknesses in terms of how TTOs operate, however, have been brought to light. One faculty member noted that TTOs should better monitor technologies after they leave the university:

"I think that the people in the TTOs are not rewarded enough for sustainability of their portfolio technologies. Their performance is based on how many patents they get out and how many spin offs and how many licenses, but there is not very much follow up with that. What happens with technology after it leaves the university is not really monitored that well by the office."

Another weakness is closely linked to institutional IP policies. Some universities require all technologies to be commercialized through the TTO, while others give researchers a choice as to whether to commercialize their innovations through the TTO or go through their own commercialization channels (see Table 2, column 3). While the obligation to commercialize via the TTO was viewed by some interviewees as a mechanism protecting the interests 
of the university employees, others expressed concerns that lack of flexibility to choose their own commercialization channels can undermine the technology's success for commercialization:

"They [the TTO] pay the initial costs of the provisional patent application which are very minimal in a way. But what happens then is they set a clock of about two years, during which one has to acquire many more pieces of data to support the next phase of the patent, and in reality in that year and a half or two years it is impossible for the researcher [in life-sciences] to acquire this data that will really enable the patent. So at the end of the two years, what happens inevitably is that the technology is deemed still too premature for commercialization, and the university cannot maintain it... The big issue I have with the TTO is they say 'Yes' to too many technologies so that they can have the monopoly on all these discoveries but they do not support them in the end... I feel that if they said 'No' earlier that would enable the researcher to look for an alternative route to commercialize. By saying 'Yes' but not having enough financial resources to do anything later sort of places the technology in a corner it cannot get out of."

A number of interviewees indicated that TTOs would function better if they had a more rigorous process of evaluating new ideas and placed a greater weight on longer-term support of fewer innovations than on short-term support of a larger number of innovations.

\subsubsection{University IP Policy}

Willingness of university researchers to engage in commercial enterprise through contract research and licensing opportunities with industry or under their own independent efforts to pursue commercialization of their research outcomes is the key to successful commercialization. To a large extent, this willingness depends on the university's IP policy. The two important dimensions of an IP policy is ownership of research results and division of income in case of successful commercialization. There are no standardized rules that govern universities' IP policies in Canada. Institutional policies with respect to ownership of research results produced by academic staff members and royalty income split are summarized in Table 3.

Table 3. Summary of IP policies for selected Canadian universities

\begin{tabular}{lll}
\hline University & $\begin{array}{l}\text { IP ownership } \\
\text { policy }\end{array}$ & Sharing of the profits (net revenue) resulting from commercialization \\
\hline $\begin{array}{l}\text { University of } \\
\text { Regina }\end{array}$ & $\begin{array}{l}\text { The inventor } \\
\text { owns IP }\end{array}$ & $\begin{array}{l}50 \% \text { of the net revenue goes to the University when it co-manages the } \\
\text { commercialization process }\end{array}$ \\
$\begin{array}{l}\text { University of } \\
\text { Saskatchewan }\end{array}$ & $\begin{array}{l}\text { The university } \\
\text { owns IP }\end{array}$ & $\begin{array}{l}50 \% \text { of the net revenue is retained by the university } \\
\text { University of }\end{array}$ \\
$\begin{array}{l}\text { Calgary } \\
\text { The inventor }\end{array}$ & $\begin{array}{l}\text { The university retains } 10-25 \% \text { when it is not involved in } \\
\text { commercialization; } 50 \% \text { goes to the University if it co-manages } \\
\text { commercialization }\end{array}$ \\
$\begin{array}{l}\text { University of } \\
\text { Alberta }\end{array}$ & $\begin{array}{l}\text { The inventor } \\
\text { owns IP }\end{array}$ & $\begin{array}{l}1 / 3 \text { of net revenues goes to the university if it is not involved in } \\
\text { commercialization; } 2 / 3 \text { of net revenues goes to the university if it } \\
\text { manages commercialization }\end{array}$ \\
$\begin{array}{l}\text { University of } \\
\text { Lethbridge }\end{array}$ & $\begin{array}{l}\text { The inventor } \\
\text { owns IP }\end{array}$ & $\begin{array}{l}25 \% \text { goes to the university if it is not involved in commercialization; } \\
\text { the university retains } 50 \% \text { if it co-manages commercialization }\end{array}$ \\
$\begin{array}{l}\text { University of } \\
\text { British } \\
\text { Columbia }\end{array}$ & $\begin{array}{l}\text { The inventor } \\
\text { owns IP }\end{array}$ & $\begin{array}{l}50 \% \text { of the Net Revenue is retained by the University, out of which } \\
25 \% \text { is allocated as general University funds and } 25 \% \text { is allocated to } \\
\text { the relevant Faculty, as identified by the University Inventor }\end{array}$
\end{tabular}




$\begin{array}{ll}\text { University of } & \text { The inventor } \\ \text { Victoria } & \text { owns IP }\end{array}$

$\begin{array}{ll}\text { Simon Fraser } & \text { The inventor } \\ \text { University } & \text { owns IP }\end{array}$

University of The inventor Western Ontario owns IP

University of Guelph

The inventor owns IP

IP is jointly

University of Toronto

McMaster University

McGill University

Waterloo University owned by the creator and the university

University owns IP

IP is jointly owned by the creator and the university

The inventor owns IP
The terms of income sharing are negotiated when the university TTO services have been utilized; $20 \%$ is retained by the university if it is interested in the IP but the creator chooses his own commercialization channels other than the university TTO

If the university is not involved in commercialization, the university retains $15 \%$ of additional annual revenues after $\$ 25,000$ in annual revenue has been received by the Creator; if the university assists with commercialization, then - after the direct costs of commercialization are repaid from revenue shared on a 50:50 basis - the University retains $30 \%$ of annual revenue; if the university is not interested in the IP and does not assist in commercializing, the university retains $5 \%$ of additional annual revenues after the first $\$ 100,000$ in annual revenue has been received by the creator

$50 \%$ is retained by the university if it assists with commercialization; the university retains $25 \%$ of the net income if it is not involved in commercialization (12.5\% in case of Free Standing Computer software)

The university retains $50 \%$ until the commercialization costs have been recovered if it has been involved in commercialization and $40 \%$ thereafter.

$25 \%$ is retained by the university if it is not involved in commercialization; if the inventor does not want to assume the legal and commercialization obligations for the invention, then the University may require the inventor to assign all his/her rights to the University in return for the first $\$ 1,000$ of, and $25 \%$ of subsequent, net revenues

$50 \%$ is retained by the university if it assists with commercialization; $25 \%$ is retained by the university if the inventor does not involve the university

Where the University is responsible for commercialization, the first $\$ 10,000$ of net royalties accrue to the inventor and of the balance of net income, $40 \%$ goes to the University; if the university is not involved in commercialization, of the first $\$ 100,000$ of net royalties, $20 \%$ goes to the university and of any net royalties above $\$ 100,000,30 \%$ goes to the University

Except when contractual arrangements have been made through informed consent or the university has provided direct support for the development of IP, the university assumes no a priori share of revenue, ownership, copyright. Reimbursement for direct support costs are negotiated between the university and the developers of the IP

Source: Authors' compilation 
As shown in Table 3, universities seem reluctant to solely claim ownership of IPs created by their faculty members: a model where ownership rights belong to the inventor is by far the most popular IP management model. Some of the interviewed faculty members felt strongly in favour of an IP model in which an inventor owns his/her invention:

"The best incentive is that what you develop you have the choice to own and so you do not need much more of an incentive than that..."

Some faculty members emphasized that one has to distinguish between ownership and control; it is university control over the technology rather than university ownership that discourages faculty members from pursuing commercialization. As seen in the table above, inventor-ownership does not necessarily translate into university researchers retaining a larger portion of commercialization income. In other words, ownership and financial rewards are not necessarily related. Therefore, a number of interviewees indicated that even in cases where the university solely owns an IP, the IP policy will not be a hindrance to commercialization as long as the TTO considers suggestions from inventors and others involved in the translation of the research and in the licensing process. One participant indicated that, on the contrary, ownership by the innovator(s) can be a hindrance to commercialization especially when multiple owners/inventors are involved:

"[Ownership by inventor] makes IP somewhat insecure actually.... It is important that the TTO is attentive and listens to inventors but as for the intellectual property ownership I think it should be owned by the university. ...If you have, say, ten people involved in a project and they all own the IP it can be very difficult to ensure the IP is completely secure."

As Table 3 reveals, income sharing arrangements vary across the universities. McGill university offers the most generous scheme of income sharing. Also, none of the interviewees viewed royalty income as a strong incentive for commercialization of their research. Several interviewees mentioned that they knew about the possibility of generating royalty income but they never considered it as a motivating factor. Scientific curiosity and translation of research results into products that can benefit the society were reported as the most important motivating factors for conducting research and pursuing commercialization.

\section{Weaknesses of the Current Commercialization Policy}

A number of weaknesses of the current research and innovation policy have been identified by the interviewees. One such weakness is that increased commercialization efforts seem to be achieved at the expense of fundamental research. Even though the overall amount of public research funding has not declined in Canada in the past decade or so, all of the interviewees acknowledged the fact that the government strategy towards what projects should be funded has shifted away from support of basic research towards more applied research. Funding streams are more and more directed with specific and short term outcomes in mind. The funding agencies are now placing more emphasis on collaboration between academia and industry through matching funds programs, support for needs-based and applied research at the expense of basic science, and increased direction of research by "end-users". One interviewee stated that:

"I think the pendulum has swung too far away from the support of basic research. As a head of department and as a contributor to the peer review of funding applications, I can appreciate the extent to which individuals who have extremely good track records and are extremely competent academically are now reaching a point where the funding is no longer sufficient to support even their basic needs. This is a clear indication that the re-direction of funding away from fundamental research and towards applied research has reached a point at which the capacity to generate ideas is seriously undermined because many of the researchers who would do that are dropping off the bottom end of the level of support."

This policy drift towards applied research and commercialization is being pushed, in part, by worries about Canada's lack of innovation and the perceived lack of success at turning academic research into commercial products. While applied research is important and is likely to show shorter term benefits, it is essential to emphasize that the long term health of an economy is dependent on a strong basic research component. Any applied research has to have a foundation in knowledge, and without continuous generation of basic knowledge there will be no applied research and commercially viable innovations in the longer term. Basic and applied research have to go hand-in-hand, rather than funding for one being replaced by funding for the other. The following quote captures the sentiment shared by all interviewees: 
"There is nothing wrong and in fact it is perfectly fine for universities and faculties to get involved in commercialization. I mean I've been doing it myself. It is a great thing. However, the problem is that the governments have been pushing us in this direction. They have been pushing us by specifically cutting funding for basic curiosity driven research and pushing that funding into applied programs. It is really clear with the latest changes at NSERC and the last federal budget. The granting agencies are being cut back and the only new funding that is available is being put into industrial programs so we are being forced in that direction. If those programs and possibilities were an add-on to a strongly supported basic curiosity driven research program that would be fine but the problem is that they are displacing the conventional grant programs and that I think is a very bad thing."

As long as universities and governments continue to push more towards commercialization at the expense of basic research, the ability of the system to generate useful applications is compromised for a number of reasons. First of all, applied research is based on basic research and, therefore, without sufficient funding for curiosity based research, applied research is jeopardized. Second, if universities abandon basic research to follow the money, then generation of new ideas most likely will diminish, because while the private sector is good at commercially exploiting ideas it is bad at generating ideas. One interviewee discussed this in the context of Big Pharma:

"We only have to look at the pharmaceutical industry to get a perfect idea of how that works and that the industry itself is very bad at generating ideas. They're very good at commercially exploiting ideas except when the regulatory process has become more and more onerous. The way Big Pharma now works is to buy ideas. They simply cannot and do not generate their own ideas and my belief is that the scientific enterprise as a whole will face that same problem if current governments both in North America and in Europe have their way and insist that scientists become commercially focused. I think it's an extremely serious problem and it's not getting the proper recognition that it deserves."

Another weakness of the current commercialization policy identified by some of the interviewees is failure of the government to realize "that people generating ideas at the bottom of the pyramid should not be responsible for commercialization. In fact they are not equipped to do so". Therefore, a successful commercialization policy has to foster the links between the different stages rather than encourage faculty to be personally involved in the commercialization.

\section{Hindrances to Commercialization of University Research in Canada: Viewpoints of Faculty and Technology Transfer Officers}

The two university-level impediments to commercialization that have been mentioned by the interviewees are related to the attitude of researchers towards commercialization and the structure of TTOs. A number of interviews suggested that "academics are generally quite conservative and are unwilling to take unnecessary chances on translational research, commit time that may distract them from their interests and obligations without a definite award". To overcome this hindrance, the universities' performance evaluation criteria have to be modified and a well defined reward system has to be developed to make it more appealing for faculty members to become involved in commercialization.

The second university-level barrier to commercialization is TTOs not functioning independently of the universities. One interviewee suggested that having a TTO as a standalone organization, free of political pressure of the university could improve the chances for a successful commercialization:

"There is political pressure to commercialize and put money into certain inventions instead of the best ones... If a researcher comes to us and he has a high profile and brings in lots of research dollars and he really feels that we should file a patent but we tell him that his research is not patentable, he may go to the higher powers who would come back to us and tell that we should go ahead and file a patent".

Most of the impediments to commercialization of academic research in Canada, however, do not lie at the university level. The major barrier to commercialization identified by almost all of the interviewees is lack of funding from both public and private sources to take early stage innovations onto a higher level of development. As was stated by one interviewee:

"The status of the Canadian venture capital community is just abysmal; investments last year were at a fifteen year low. They are the same level as 1994 and they haven't historically in the 
last couple of years had a lot of money and certainly are not putting it into the early stage phase."

Lack of venture capital translates into difficulties for faculty members in life-sciences to secure funding from various government programs that require matching funds from the industry. Lifting this requirement, however, would not be appropriate, because matching funds from the private sector demonstrates a certain level of commitment. As an alternative solution, one participant suggested that the government could launch a program to lend money to small companies that would use the money as the matching funds.

The second major barrier identified by all participants is the lack of receptor capacity in the field of life-sciences. One participant indicated that in Canada "there has not really been a culture of developing companies that would stay in Canada and become solidly implanted in Canada." With companies closing down their R\&D efforts in Canada one after another, the likelihood of a collaboration with the private sector and, consequently, commercialization of end products is becoming smaller.

The third major impediment is tied to lack of management skills, which is supported by the following quotes:

“...we do not have a long standing history of small technology companies growing into large technology companies and so we don't have a history of success in that regard. We also have a smaller pool of management expertise and those managers that have been active remain active. So what we need to do is promote new people going into translational research and into business. It needs to be more vibrant and turbulent field so that the people who are successful can succeed and the people who are not successful, they eventually have to leave the area."

“... if you go and decide that you want to form a start up, most academics can't manage a company and they need professional help - somebody who knows how to get financing and how to do accounting and somebody who knows the HR to hire people and make sure that the people are managed properly, to run the payroll. It's those kinds of skills running a start-up company that are really very different from being a successful scientist. Some people try to do it and succeed, most don't succeed when they try to become a CEO and those are the skills which don't seem to be available outside the mining and resource factor in this country. So from my view as an academic, that's where we need help."

\section{Conclusions}

This paper has discussed the efforts of the government and Canadian universities to promote commercialization of university research. The attention was limited to commercialization practices in life-sciences. The results of the study are drawn from the interviews with the technology transfer officers and faculty members at nine Canadian universities. While there is no doubt that various government initiatives have strengthened the cooperation between university researchers and industry, thus helping commercialization process, the major weakness of the current commercialization policy is a drastic shift towards funding of applied science projects and reduced pot of money for funding basic research as identified by the interviewees. Most of the interviewees expressed their concerns that the shift towards applied research away from basic and stronger emphasis on partnerships of university scientists with the private sector is significantly undermining the ability of the higher education sector to generate new ideas. The major hindrances to commercialization in Canada as identified by the respondents are lack of venture capital and receptor capacity, which makes it difficult for scientists in life-sciences to get access to funding requiring matching funds from the industry.

It should, however, be noted that the analysis in this study was based on the interviews with a relatively small number of faculty members in the field of life-sciences and, therefore, there may be a potential for some selectivity bias. Most of the participants were from large universities that are hubs of commercialization of university research and the study does not fully represent the viewpoints of faculty members from smaller universities. This is the major limitation of the study, which can be overcome by increasing the sample size and surveying a larger number of faculty members, in particular, from the universities where commercialization activities are limited. As part of further research it would be interesting to perform some econometric analysis to see the relationship between IP ownership, university control of commercialization, percentage of royalties retained by the researcher and commercialization output.

\section{Acknowledgements}

This research has been funded by the University of Regina President's SSHRC fund. We would also like to thank faculty members and technology transfer officers who agreed to participate in this study. 


\section{References}

ACCC (Association of Canadian Community Colleges). (2013). The College and Community Innovation Program: Smart Investment for Business. Retrieved from www.accc.ca

CFI database. Retrieved July 20, 2013, from http://www.innovation.ca/en/OurInvestments/Projectsfunded

CIHR Awards Search. Retrieved from http://webapps.cihr-irsc.gc.ca/funding/search_e\#Agency

Conference Board of Canada. (2013). How Canada performs. Retrieved July 18, 2013, from http://www.conferenceboard.ca/hcp/details/innovation.aspx

Den Tandt, Michael. (2013). Behold, the revamped National research Council - now at your service. National Post, May 7, 2013. Retrieved July 16, 2013, from http://fullcomment.nationalpost.com/2013/05/07/michael-den-tandt-4/

Goss Gilroy Inc. (2008). Evaluation of the Intellectual Property Mobilization Program: Final Evaluation report. Report prepared for the NSERC. Retrieved July 17, 2013, from http://www.nserc-crsng.gc.ca/_doc/Reports-Rapports/evaluations/IPM_Final_Report_FINAL-ATIP_2008_e.pdf

Holstein, J.A., \& Gubrium, J.F. (1995). The Active Interview. Thousand Oaks: Sage Press.

Industry Canada. (2013). Harper Government Helps Colleges Support Business Innovation. Retrieved July 20, 2013, from http://news.gc.ca/web/article-eng.do?nid=732929

NSERC Awards Search Engine. Retrieved from http://www.outil.ost.uqam.ca/CRSNG/Outil.aspx?Langue=Anglais

Science, Technology and Innovation Council. (2013). State of the Nation 2012. Canada's Science, Technology and Innovation System: Aspiring to Global Leadership. Retrieved July 15, 2013, from www.stic-csti.ca

$\begin{array}{lllll}\text { SSHRC Awards } & \text { Search } & \text { Engine. } & \text { Retrieved }\end{array}$ http://www.outil.ost.uqam.ca/CRSH/RechProj.aspx?vLangue=Anglais

Statistics Canada. Table 358-0025 - Survey of intellectual property commercialization, by higher education sector indicators, annual (number unless otherwise noted), CANSIM (database). (July 22, 2013)

Statistics Canada. Table 358-0162 - Provincial estimates of research and development expenditures in the higher education sector, by funding sector and type of science, annual (number), CANSIM (database) (July 18, 2013).

\section{Notes}

Note 1. By commercialization we mean "the process through which discoveries are brought to the marketplace and new ideas and discoveries are developed into new products, services or technologies that are sold around the world" (The Government of Canada, 2004).

Note 2. University of British Columbia, Simon Fraser University, University of Victoria, University of Alberta, University of Saskatchewan, University of Regina, McGill University, McMaster University.

Note 3. ACCC (2013) reports that, since 2002, the federal government has awarded $\$ 192.3$ million for 370 projects at 72 colleges. However, we could not validate this number as the statistics on research awards that we compiled from NSERC and SSHRC Awards Search Engines indicated that $\$ 62.1$ million worth of grants was awarded up to $2011 / 2012$.

Note 4. For our sample, the creation of the ILO at the University of Regina was the initiative of the municipal government and currently the City contributes about $90 \%$ of the ILO's budget. TEC Edmonton (the commercialization hub for the University of Alberta) is an independent enterprise owned by the university and the City and receives significant support from the City of Edmonton.

Note 5. For our sample, the ILO at the University of Saskatchewan supports its operations through licensing income with the university contributing only $3 \%$ to the TTO's budget. 